\title{
小児の脳低温療法：エビデンスの日陰における葛藤
}

これまでにpeer review誌に掲載された 500 とも 1,000 とも言われる実験的脳保護療法が,一向に臨床 症例に押いて再現性のある効果を見せられない中で, 脳低温療法は唯一, 新生児脳症と成人の蘇生後脳症に おいて, 有効な治療法として認識されつつある11。脳 低温療法は, 他の様々な類縁病態においても熱い期待 を集め, 数々の臨床試験や現場における試験的施行に つながっている。

脳温の低下は, エネルギー消費の抑制・細胞傷害性 毒素の軽減を根幹とする, 広い範囲にわたる組織保護 効果をもたらすことが知られている1)。また，頭蓋内 圧六進が顕著な病態では, 強力な脳圧降下作用を期待 して導入・維持されることも少なくない。このような 直接作用に加えて, 脳低温療法は, 他の薬剤による脳 保護効果の有効域を延長する作用も併せ持つため, 今 後併用療法への期待が高まっている2)。

低体温による合併症は多岐にわたり，呼吸循環抑 制 - 血流調節異常 - 血液凝固異常 - 免疫異常 - 交感神 経刺激・熱産生増加・組織での酸素受け渡し障害など が指摘されている。しかしながら，これらの中には， 生体が低温状態に適応するための合目的な反応も含ま れていると考えられ，正常体温時の “正常値”を維持す るために，血圧や凝固系を操作することには慎重な意 見も多(3)。

脳低温状態による脳保護効果と副反応のバランス は, 受傷形態・患者背景・合併症だけでなく, 脳内の 部位によっても異なることが示唆されているため, 至 適冷却法・温度・時間・離脱法に関する唯一最善の方 法は存在しない可能性が高い4)。低体温麻醉などの予 防的低体温と異なり, 受傷後に脳を冷却する場合には, 安全冷却温度域は非常に狭く, 一般に $32^{\circ} \mathrm{C}$ を下回る温 度域では, 合併症が脳保護効果を上回ることが危惧さ れている11。実験モデルでは, 冷却時間が長ければ長 いほど, 脳保護効果は増強されるが, 72 時間を超える 冷却を比較した検討は稀であり，長期冷却の安全性・ 有効性に関するまとまった情報はない。海外の臨床研 究では, 主に医療資源と感染症合併の観点から, 長期 冷却と緩徐な離脱を採用しない例が多い5)。さらに, 発達中の脳においては, 長期間神経回路が遮断される
ことによる廃用性淘汰の危険も否定できず，引き続き 慎重な基礎研究成果の解釈と検証が望まれる6)。

これまでに脳低温療法が臨床応用された病態のう ち, その予後改善効果が実践的なセッティングで証明 されたのは, 新生児脳症と成人の心停止・蘇生後脳症 に限られ, 頭部外傷・脳出血・脳梗塞では, 未だに芳 しい結果にはつながっていない5)。“クリーン”な低酸 素虚血後脳症だけでなく, 感染や出血・血管攣縮など の重篤な合併症を来す病態において, 脳低温療法の有 効性を証明するには, 更なるプロトコールの改善が必 要になると予想される。また, 病態を問わず, 胹低温 療法は最重症例には無効であることが, 多方面から報 告されている1)。これは, 最重症例に打いては合併症 だけでなく, 治療可能な時間域が著しく短縮されてい ることが原因と考えられ, 重症度に応じた迅速な冷却 導入が要求されるかもしれない7)。

新生児脳症において, $10^{\circ} \mathrm{C}$ 超の局所脳温の差が生じ ると予想される全身冷却と頭部冷却が，ほほ同等の予 後改善効果につながっていることは興味媣い1)。この ことから, 冷却するか否かが重要であり, プロトコー ルは二の次である, と解釈する向きもある。しかし, 動物モデルにおいて, わずか $1 \sim 2^{\circ} \mathrm{C}$ の脳温変化で脳傷 害パターンが劇的に変化することから考えると，2つ の冷却プロトコールが, それぞれの持つ長所・短所の 影響を受けながら，偶然同等の水準に着地した可能性 を支持したい4)。そうだとすれば，脳低温療法による 脳保護効果は, 更なる微調整によって, 飛躍的に改善 する余地がある。

我が国では欧米に比べ, 経験症例からより多くを学 ぶ傾向にあるため, たとえ新しい治療法であっても, 臨床医が治療効果に対して強い思い入れを持っている ことが多い。したがって我が国では, 細かく粘り強い 症例観察から, 著効例・不運な合併症を招いた症例な どを深く分析し, プロトコールを進化させることに長 けているものの, ランダム化比較試験を受け入れる余 地が少ないため, 重要な臨床エビデンスのほとんどは 欧米から発信されてきた。一方, 欧米に打いては, 臨 床研究を施行するために必要な医療資源は, 原則とし て研究プロジェクトのために獲得した基金から償却さ 
れるため, 単一のわかりやすい作業仮説を比較的短期 間の介入で明らかにしようとするものが主流である。 したがって, 前述のような, 細やかな温度・脳圧管理 と長期冷却・緩徐離脱をセットにしたプロトコールの 優位性を証明することは, 極めて困難である。

今後我が国では，できるだけ作業仮説を集約したう えで, 各施設が譲歩・協力し合って情報を蓄積し, ラ ンダム化比較試験実現に向けて努力を重ねていく必要 がある。このためには準備段階として, 基礎研究や臨 床経験からのフィードバックを慎重に吟味し, 飛躍の 少ない解釈から臨床応用を模索し, トランスレーショ ナル研究を駆使しながら，多くの施設が受け入れ可能 なプロトコールを磨いていく必要がある。複数のラン ダム化比較試験によるメ夕解析によって効果が支持さ れることが, 新しい介入療法にとっての最終審判では あるが, ランダム化比較試験以外の研究からのフィー ドバックを軽んじる近年の傾向も嘆かわしい。筆者ら は, 協賛施設から過去の症例情報提供を得て, 小児脳 症に対する脳低温療法の効果を間接的に証明する取り 組みをしている8)。すなわち, バイアスの多い多施設 の症例を無理に“常温対低温”で比較するのではなく， 発症から脳低温療法導入までの時間経過と予後スコア を比較し, 脳低温療法の効果を間接的に支持する情報 を得ている。このように, いきなり標準過程であるラ ンダム化比較試験を目指すのでなく, 大規模な症例の 蓄積・分析から, ランダム化比較試験実現のために必 要な支持デー夕を集積する努力がもっとなされて良い と思われる。

今号に掲載された林らによる検討症例は9), 入院時 の神経学的所見こそ重症であったが, (1)心停止による 比較的合併症の少ない低酸素虚血であったこと, (2)心 停止の約 5 分後に医師による蘇生が開始されたこと, (3) 3 次施設搬入時には軽度低体温状態であったことな どから, 脳低温療法の好適応であったと考えられる。 補助療法に関しては, 前述のように様々な意見が入り 乱れているが, 林らは III相試験で採用されている標準 的管理を基本的に踏襲することで, 理想的な成果を達 成している。また，このような貴重な症例を論文とし てだれもがアクセス可能な形で蓄積する姿勢は賞賛に 值する。今後, 失敗例も含めてこのような症例が 1 例 でも多くデータベースに蓄積され, 我が国ならではの 緻密なプロトコールによるランダム化比較試験が執り 行われることを期待したい。

\section{岩田 欧介}

久留米大学小児科・高次脳疾患研究所

（ ₹ 830-0011 福岡県久留米市旭町 67）

Therapeutic hypothermia for child encephalopathy: what clinicians can do when the best available evidence is too poor

Key words: (1) therapeutic hypothermia, (2) optimal temperature, (3) patient selection

Osuke Iwata

Center for Developmental \& Cognitive Neuroscience, Department of Pediatrics \& Child Health, Kurume University School of Medicine

67 Asahimachi, Kurume, Fukuoka 830-0011, Japan

J Jpn Soc Intensive Care Med. 2010;17:9 10.

\section{文 献}

1) Robertson NJ, Iwata O. Bench to bedside strategies for optimizing neuroprotection following perinatal hypoxiaischaemia in high and low resource settings. Early Hum Dev. 2007;83:801-11.

2) Gladstone DJ, Black SE, Hakim AM. Toward wisdom from failure: lessons from neuroprotective stroke trials and new therapeutic directions. Stroke. 2002;33:2123-36.

3) Erecinska M, Thoresen M, Silver IA. Effects of hypothermia on energy metabolism in Mammalian central nervous system. J Cereb Blood Flow Metab. 2003; 23:513-30.

4) Iwata O, Thornton JS, Sellwood MW, et al. Depth of delayed cooling alters neuroprotection pattern after hypoxia-ischemia. Ann Neurol. 2005;58:75-87.

5) Bernard S. Hypothermia after cardiac arrest: expanding the therapeutic scope. Crit Care Med. 2009;37:S227-33.

6) Ikonomidou C, Stefovska V, Turski L. Neuronal death enhanced by N-methyl-D-aspartate antagonists. Proc Natl Acad Sci U S A. 2000;97:12885-90.

7) Iwata O, Iwata S, Thornton JS, et al. "Therapeutic time window" duration decreases with increasing severity of cerebral hypoxia-ischaemia under normothermia and delayed hypothermia in newborn piglets. Brain Res. 2007; 1154:173-80.

8) Kawano G, Iwata O, Okada E, et al. Therapeutic hypothermia for acute encephalopathy in childhood: A pilot study. Pediatric Academic Societies' Annual Meeting. 2008;4504-6.

9) 林 振作, 橘 一也, 竹内宗之, 他. 脳低温療法を施行し た蘇生後脳症の 1 乳児例. 日集中医誌. 2010;17:49-53.

受付日 2009 年 7 月 31 日 採択日 2009 年 8 月 18 日 